\title{
Solirubrobacter ginsenosidimutans sp. nov., isolated from soil of a ginseng field
}

\author{
Correspondence \\ Wan-Taek Im \\ wandra@kaist.ac.kr
}

\author{
Dong-Shan An, ${ }^{1 \dagger}$ Liang Wang, ${ }^{1 \dagger}$ Minseok S. Kim, ${ }^{2}$ Heon-Meen Bae, ${ }^{3}$ \\ Sung-Taik Lee ${ }^{1}$ and Wan-Taek $\operatorname{Im}^{1}$
}

\author{
${ }^{1}$ Department of Biological Sciences, Korea Advanced Institute of Science and Technology, 373-1, \\ Guseong-dong, Yuseong-gu, Daejeon 305-701, Republic of Korea \\ ${ }^{2}$ Emerging Technology Research Center, Samsung Advanced Institute of Technology (SAIT), \\ San14, Nongseo, Giheung-gu, Yongin-si, Gyeonggi-do 446-712, Republic of Korea \\ ${ }^{3}$ Marine Ecology Research Division, National Fisheries Research \& Development Institute, 152-1, \\ Haean-ro, Gijang-eup, Gijang-gun, Busan 619-705, Republic of Korea
}

The genus Solirubrobacter was established by Singleton et al. (2003) with the description of a single species, Solirubrobacter pauli, isolated from a burrow of the earthworm Lumbricus rubellus in agricultural soil in Georgia, USA (Furlong et al., 2002). Later, the species Solirubrobacter soli was isolated from soil of a ginseng field in South Korea (Kim et al., 2007). Members of the genus Solirubrobacter are characterized as Gram-positive, non-spore-forming, aerobic and catalase-positive rods, with $\mathrm{C}_{18: 1} \omega 9 c$ and iso- $\mathrm{C}_{16: 0}$ as

†These authors contributed equally to this work.

Abbreviations: $\mathrm{Rb}_{1}, 3-\mathrm{O}$-[ $\beta$-D-glucopyranosyl-(1-2)- $\beta$-D-glucopyranosyl]-20O-[ $\beta$-D-glucopyranosyl-(1-6)- $\beta$-D-glucopyranosyl]-20(S)-protopanaxadiol; $\mathrm{Rd}, 3-O-[\beta$-D-glucopyranosyl-(1-2)- $\beta$-D-glucopyranosyl]-20-O- $\beta$-D-glucopyranosyl-20(S)-protopanaxadiol; $\mathrm{F}_{2}$, 3-O-( $\beta$-D-glucopyranosyl)-20-O- $\beta$ D-glucopyranosyl-20(S)-protopanaxadiol.

The GenBank/EMBL/DDBJ accession number for the 16S rRNA gene sequence of strain BXN5-15 ${ }^{\top}$ is EU332825.

A supplementary table and a supplementary figure are available with the online version of this paper. the major fatty acids and DNA G $+\mathrm{C}$ contents of 71.5$71.8 \mathrm{~mol} \%$.

During the course of a study on the cultivable aerobic bacterial community in soil of a ginseng field on Baekdu Mountain in China, a large number of novel bacterial strains were isolated. One of these isolates, strain BXN5-15 ${ }^{\mathrm{T}}$, appeared to be a member of genus Solirubrobacter and converted ginsenoside $\mathrm{Rb}_{1}\{3-O-[\beta$-D-glucopyranosyl-(1-2)$\beta$-D-glucopyranosyl]-20-O-[ $\beta$-D-glucopyranosyl-(1-6)- $\beta$-Dglucopyranosyl]-20(S)-protopanaxadiol $\}$ via $\mathrm{Rd}\{3-O-[\beta-\mathrm{D}-$ glucopyranosyl-(1-2)- $\beta$-D-glucopyranosyl]-20- $O$ - $\beta$-D-glucopyranosyl-20 $(S)$-protopanaxadiol $\}$ to minor ginsenoside $\mathrm{F}_{2}$ [3-O-( $\beta$-D-glucopyranosyl $)-20-O$ - $\beta$-D-glucopyranosyl20(S)-protopanaxadiol].

For isolation of strain $\mathrm{BXN5}-15^{\mathrm{T}}$, a soil sample was thoroughly suspended and serially diluted in $50 \mathrm{mM}$ phosphate buffer ( $\mathrm{pH} 7.0$ ) and spread on modified xylan-nutrient agar comprising $\left(\mathrm{l}^{-1}\right) 0.02 \mathrm{~g}$ Tryptone, $0.02 \mathrm{~g}$ yeast extract, $0.02 \mathrm{~g}$ malt extract, $0.02 \mathrm{~g}$ beef extract, $0.02 \mathrm{~g}$ Casamino acid, $0.02 \mathrm{~g}$ Soytone, $1.0 \mathrm{~g}$ xylan, $0.1 \mathrm{~g}$ 
sodium pyruvate, $0.3 \mathrm{~g} \mathrm{~K}_{2} \mathrm{HPO}_{4}, 0.05 \mathrm{~g} \mathrm{MgSO}_{4}, 0.05 \mathrm{~g}$ $\mathrm{CaCl}_{2}, 15 \mathrm{~g}$ agar; $\mathrm{pH}$ 7.0). The plates were incubated at $30{ }^{\circ} \mathrm{C}$ for 1 month. Strain BXN5-15 ${ }^{\mathrm{T}}$ was cultured routinely on R2A agar (Difco) at $25^{\circ} \mathrm{C}$ and preserved in $20 \%(w / v)$ glycerol at $-70{ }^{\circ} \mathrm{C}$.

The genomic DNA of strain BXN5-15 ${ }^{\mathrm{T}}$ was extracted using a commercial genomic DNA-extraction kit (Solgent). The $16 S$ rRNA gene was amplified using the universal bacterial primer pair 9F and 1512R and the purified PCR products were sequenced by Solgent (Ten et al., 2008). An almostcomplete sequence of the $16 \mathrm{~S}$ rRNA gene was compiled using SeqMan software (DNASTAR). 16S rRNA gene sequences of related taxa were obtained from the GenBank database and the EzTaxon server (http://www.eztaxon.org/; Chun et al., 2007). Multiple alignments were performed using CLUSTAL X (Thompson et al., 1997) and gaps were edited using BioEdit (Hall, 1999). Evolutionary distances were calculated using the Kimura two-parameter model (Kimura, 1983). Phylogenetic trees were reconstructed using the neighbour-joining (Saitou \& Nei, 1987) and maximum-parsimony (Fitch, 1971) methods using MEGA version 4 (Kumar et al., 2008) and bootstrap values were calculated from 1000 replications (Felsenstein, 1985).

The 16S rRNA gene sequence of strain BXN5-15 determined in this study was a continuous stretch of 1490 bp (base positions 24-1507 with respect to the Escherichia coli numbering system). Sequence similarity calculations indicated that the closest relatives of the isolate were S. soli Gsoil $355^{\mathrm{T}}$ (98.4\% 16S rRNA gene sequence similarity) and $S$. pauli $\mathrm{B} 33 \mathrm{D}^{\mathrm{T}}(96.4 \%)$. Sequence similarities $<96.0 \%$ were found with all other recognized members of the order Solirubrobacterales. The relationship between strain BXN5-15 $5^{\mathrm{T}}$ and members of the order Solirubrobacterales was also evident in the phylogenetic tree (Fig. 1). On the basis of the phylogenetic inference, S. soli KCTC $12628^{\mathrm{T}}$ and S. pauli KCTC $9974^{\mathrm{T}}$ were used as reference strains for most phenotypic tests and for DNADNA hybridization studies.

The Gram-reaction was performed by the non-staining method as described by Buck (1982). Morphology and motility of cells grown for 3 days at $30{ }^{\circ} \mathrm{C}$ on R2A agar were determined by using light microscopy (E600; Nikon) and transmission electron microscopy (negative staining with $1 \%$, w/v, phosphotungstic acid; CM-20; Philips).
Catalase activity was assessed by bubble production in $3 \%$ (v/v) $\mathrm{H}_{2} \mathrm{O}_{2}$ and oxidase activity was determined using $1 \%(\mathrm{w} / \mathrm{v})$ tetramethyl- $p$-phenylenediamine. Carbon-source utilization and enzyme activities were tested using API 20 NE, API ID 32 GN and API ZYM kits (bioMérieux), according to the manufacturer's instructions. Growth at 4, $10,18,25,30,37,42$ and $45{ }^{\circ} \mathrm{C}$ was assessed after 7 days on R2A agar. Growth at pH 5.0-10.0 (at intervals of $0.5 \mathrm{pH}$ units) was assessed after 7 days in $\mathrm{R} 2 \mathrm{~A}$ broth with the $\mathrm{pH}$ adjusted using the following buffer system (final concentration $50 \mathrm{mM}$ ): $\mathrm{pH}$ 5.0-5.5, acetate buffer; $\mathrm{pH}$ 6.0-8.0, phosphate buffer; and $\mathrm{pH} 8.5-10.0$, Tris buffer. Growth in $1-10 \%(\mathrm{w} / \mathrm{v}) \mathrm{NaCl}$ (at intervals of $1 \% \mathrm{NaCl}$ ) was assessed after 7 days in R2A broth by monitoring $\mathrm{OD}_{600}$. Anaerobic growth was tested in serum bottles by adding $1 \mathrm{~g}$ thioglycolate $1^{-1}$ to $\mathrm{R} 2 \mathrm{~A}$ broth and substituting the gas phase with nitrogen gas. Growth was also evaluated on trypticase soy agar (TSA; BD) and MacConkey agar (BD) at $30{ }^{\circ} \mathrm{C}$. Conversion of ginsenoside $\mathrm{Rb}_{1}$ was assessed using TLC and HPLC as described by Kim et al. (2005).

Cells of strain BXN5-15 ${ }^{\mathrm{T}}$ were Gram-reaction-positive, strictly aerobic, non-spore-forming, non-motile, oxidaseand catalase-positive rods (Supplementary Fig. S1, available in IJSEM Online). $\beta$-Glucosidase activity was detected in strain BXN5-15 $5^{\mathrm{T}}$; this activity was responsible for the gradual conversion of ginsenoside $\mathrm{Rb}_{1}$ to compound $\mathrm{F}_{2}$ (data not shown). The morphological, physiological and biochemical characteristics of strain BXN5-15 ${ }^{\mathrm{T}}$ are given in the species description and Table 1.

To measure the $\mathrm{G}+\mathrm{C}$ content of the chromosomal DNA of strain BXN5-15 ${ }^{\mathrm{T}}$, genomic DNA was extracted and purified as described by Moore \& Dowhan (1995) and the $G+C$ content was determined as described by Mesbah et al. (1989) using reversed-phase HPLC. Cellular fatty acid compositions of the isolate and the reference strains were determined using cells grown on R2A agar for 3 days according to the protocol of the Sherlock Microbial Identification System (MIDI). Fatty acid methyl esters were analysed by GC (6890; Hewlett Packard) and identified by Microbial Identification software (Sasser, 1990). For the determination of isoprenoid quinones, strain BXN5-15 $5^{\mathrm{T}}$ was grown in R2A broth for 5 days at $30{ }^{\circ} \mathrm{C}$ and harvested cells were lyophilized for $24 \mathrm{~h}$. Isoprenoid quinones were extracted with chloroform/ methanol $(2: 1, \mathrm{v} / \mathrm{v})$, evaporated under vacuum and

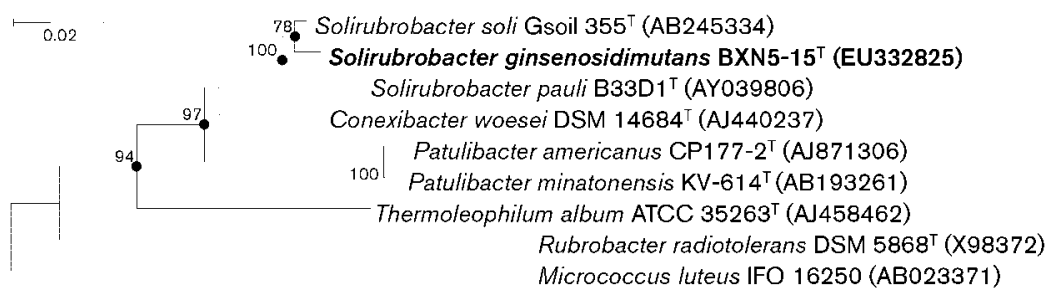

http://ijs.sgmjournals.org
Fig. 1. Neighbour-joining phylogenetic tree based on 16S rRNA gene sequences (1400 bp), showing the relationship of strain BXN5-15 ${ }^{\top}$ with related taxa. Bootstrap values $(>70 \%)$ based on 1000 replications are shown at branch nodes. Filled circles indicate corresponding nodes that were also recovered in the tree generated with the maximumparsimony algorithm. Bar, 0.02 substitutions per nucleotide position. 
Table 1. Differentiating characteristics of strain BXN5-15 ${ }^{\top}$ and type strains of species of the genus Solirubrobacter

Strains: 1, Solirubrobacter ginsenosidimutans sp. nov. BXN5-15 ${ }^{\mathrm{T}} ; 2, S$. soli KCTC $12628^{\mathrm{T}}$; 3, S. pauli KCTC $9974^{\mathrm{T}}$. Data were taken from this study unless otherwise indicated. All strains were Gram-reactionpositive rods and positive for catalase, esterase (C4), esterase lipase (C8), leucine arylamidase, $\alpha$-glucosidase and $\beta$-glucosidase. All strains were negative for lipase (C14), cystine arylamidase, trypsin, $\alpha$ chymotrypsin, $\alpha$-fucosidase, $\alpha$-galactosidase, $\beta$-glucuronidase, arginine dihydrolase, urease, production of indole, acid production from glucose and reduction of nitrate to nitrite. +, Positive; w, weakly positive; -, negative.

\begin{tabular}{|c|c|c|c|}
\hline Characteristic & 1 & 2 & 3 \\
\hline Cell length $(\mu \mathrm{m})^{\star}$ & $1.8-2.5$ & $1.0-3.0$ & 1.5 \\
\hline \multicolumn{4}{|l|}{ Growth temperature $\left({ }^{\circ} \mathrm{C}\right)^{\star}$} \\
\hline Range & $18-37$ & $15-30^{*}$ & $19-38^{*}$ \\
\hline Optimum & 30 & $25-30^{\star}$ & $28-30^{\star}$ \\
\hline Growth in $1 \% \mathrm{NaCl}$ & - & + & - \\
\hline \multicolumn{4}{|l|}{ API $20 \mathrm{NE}$} \\
\hline Oxidase & + & $\mathrm{w}$ & - \\
\hline Gelatin hydrolysis & - & + & - \\
\hline \multicolumn{4}{|l|}{ Assimilation of: } \\
\hline Glucose & - & + & $\mathrm{w}$ \\
\hline Arabinose & + & + & $\mathrm{w}$ \\
\hline Mannose & - & + & + \\
\hline Mannitol & $\mathrm{w}$ & $\mathrm{w}$ & - \\
\hline $\mathrm{N}$-Acetylglucosamine & - & $\mathrm{w}$ & - \\
\hline Maltose & - & + & - \\
\hline Gluconate & + & $\mathrm{W}$ & + \\
\hline Adipate & - & $\mathrm{w}$ & - \\
\hline \multicolumn{4}{|l|}{ API ZYM } \\
\hline Valine arylamidase & $\mathrm{W}$ & + & + \\
\hline $\begin{array}{l}\text { Naphthol-AS-BI- } \\
\text { phosphohydrolase }\end{array}$ & - & - & + \\
\hline$N$-Acetyl- $\beta$-glucosaminidase & - & + & - \\
\hline$\alpha$-Mannosidase & - & - & + \\
\hline$\beta$-Galactosidase & + & - & - \\
\hline DNA G $+\mathrm{C}$ content $(\mathrm{mol} \%)$ & 70.6 & $71.5^{\star}$ & $71.8^{*}$ \\
\hline
\end{tabular}

${ }^{\star}$ Data were taken from Singleton et al. (2003) and Kim et al. (2007).

re-extracted in $\mathrm{n}$-hexane/water $(1: 1, \mathrm{v} / \mathrm{v})$. The crude n-hexane/quinone solution was purified using Sep-Pak Vac silica cartridges (Waters) and subsequently analysed by HPLC as described by Hiraishi et al. (1996). DNA-DNA hybridization was performed between strain BXN5- $15^{\mathrm{T}}$ and S. soli KCTC $12628^{\mathrm{T}}$ using the method described by Ezaki et al. (1989) with photobiotin-labelled DNA probes and microdilution wells. Hybridization was performed reciprocally with five replications for each sample. The highest and lowest values obtained for each sample were excluded and the mean of the remaining three values was converted to obtain a DNA-DNA relatedness value.

The DNA G+C content of strain BXN5-15 $5^{\mathrm{T}}$ was $70.6 \mathrm{~mol} \%$, which is similar to those of $S$. pauli and $S$. soli (Table 1). The respiratory quinone system of strain BXN5-15 $5^{\mathrm{T}}$ was MK-7 $\left(\mathrm{H}_{4}\right)$, which is consistent with the quinone systems of members of the genus Solirubrobacter (Kim et al., 2007). The fatty acid profiles of strain BXN5$15^{\mathrm{T}}$ and the reference strains are shown in Supplementary Table S1. The major fatty acids of strain BXN5 $-15^{\mathrm{T}}$ were $\mathrm{C}_{18: 1} \omega 9 c(14.8 \%)$ and iso- $\mathrm{C}_{16: 0}(12.9 \%)$, which were typical of the genus Solirubrobacter, and $\mathrm{C}_{18: 3} \omega 6,9,12 c$ $(11.1 \%)$, which was not found in S. soli KCTC $12628^{\mathrm{T}}$. Minor fatty acids (2-10\%) were iso- $\mathrm{C}_{16: 0} 3-\mathrm{OH}(7.9 \%)$, $\mathrm{C}_{17: 1} \omega 6 c(6.2 \%)$, iso- $\mathrm{C}_{19: 0}(5.9 \%)$, iso- $\mathrm{C}_{20: 0}(5.2 \%)$, $\mathrm{C}_{18: 0}(5.1 \%), \mathrm{C}_{16: 0}(4.7 \%), \mathrm{C}_{20: 4} \omega 6,9,12,15 c(4.0 \%)$, iso$\mathrm{C}_{18: 0}(2.3 \%)$ and $\mathrm{C}_{14: 0}(2.1 \%)$. Some minor qualitative and quantitative differences in fatty acid content were observed between strain BXN5-15 $5^{\mathrm{T}}$ and its closest relatives. DNA-DNA relatedness between strain BXN5-15 ${ }^{\mathrm{T}}$ and $S$. soli KCTC $12628^{\mathrm{T}}$ was (mean $\pm \mathrm{SD}$ ) $23.3 \pm 4.8 \%$ (reciprocal experiment, $20.8 \pm 4.2 \%$ ). These values are low enough to assign strain BXN5-15 $5^{\mathrm{T}}$ to a novel species of genus Solirubrobacter (Wayne et al., 1987).

In summary, the characteristics of strain BXN5- $15^{\mathrm{T}}$ were consistent with descriptions of the genus Solirubrobacter with regard to morphological, biochemical and chemotaxonomic properties. However, the phylogenetic distances and the low level of DNA-DNA relatedness between strain BXN5- $15^{\mathrm{T}}$ and recognized members of the genus Solirubrobacter and the unique phenotypic characteristics (Table 1) warrant assignment of strain BXN5- $15^{\mathrm{T}}$ to the genus Solirubrobacter as a novel species, for which the name Solirubrobacter ginsenosidimutans sp. nov. is proposed.

\section{Description of Solirubrobacter ginsenosidimutans sp. nov.}

Solirubrobacter ginsenosidimutans (gin.se.no.si.di.mu'tans. N.L. n. ginsenosidum ginsenoside; L. part. adj. mutans transforming, converting; N.L. part. adj. ginsenosidimutans ginsenoside-converting).

Cells are Gram-reaction-positive, non-motile, non-sporeforming, aerobic rods $(0.4-0.6 \mu \mathrm{m}$ wide, $1.8-2.5 \mu \mathrm{m}$ long after culture on R2A agar for 3 days). Colonies are smooth, circular, convex, yellow and $0.6-1.2 \mathrm{~mm}$ in diameter. Grows at $18-37{ }^{\circ} \mathrm{C}$ (optimum $30{ }^{\circ} \mathrm{C}$ ), but not at 10 or $42{ }^{\circ} \mathrm{C}$, at $\mathrm{pH}$ 6.0-7.0 (optimum pH 7.0) and in $<1.0 \%$ (w/v) NaCl. Catalase- and oxidase-positive. Grows on nutrient agar and TSA agar, but not on MacConkey agar. Sole carbon sources (API 20 NE and API ID 32GN) and enzyme activities (API $\mathrm{ZYM}$ ) are listed in Table 1. In addition, gluconate is utilized as a sole carbon source, but caprate, malate, citrate and phenylacetate are not. Does not reduce nitrate to nitrite or nitrogen gas. MK- $7\left(\mathrm{H}_{4}\right)$ is the predominant menaquinone. The major fatty acids $(>7 \%)$ are $\mathrm{C}_{18: 1} \omega 9 \mathrm{c}$, iso- $\mathrm{C}_{16: 0}$, $\mathrm{C}_{18: 3} \omega 6,9,12 c$ and iso- $\mathrm{C}_{16: 0} 3-\mathrm{OH}$.

The type strain, BXN5-15 ${ }^{\mathrm{T}}$ (=KACC $20671^{\mathrm{T}}=\mathrm{LMG}$ $\left.24459^{\mathrm{T}}\right)$, was isolated from soil of a ginseng field on Baekdu Mountain, China. The DNA G+C content of the type strain is $70.6 \mathrm{~mol} \%$. 


\section{Acknowledgements}

This work was supported by the 21C Frontier Microbial Genomics and Applications Center Program, Ministry of Education, Science \& Technology (grant number MG08-0101-2-0), Republic of Korea.

\section{References}

Buck, J. D. (1982). Nonstaining (KOH) method for determination of gram reactions of marine bacteria. Appl Environ Microbiol 44, 992-993.

Chun, J., Lee, J.-H., Jung, Y., Kim, M., Kim, S., Kim, B. K. \& Lim, Y.-W. (2007). EzTaxon: a web-based tool for the identification of prokaryotes based on $16 \mathrm{~S}$ ribosomal RNA gene sequences. Int J Syst Evol Microbiol 57, 2259-2261.

Ezaki, T., Hashimoto, Y. \& Yabuuchi, E. (1989). Fluorometric deoxyribonucleic acid-deoxyribonucleic acid hybridization in microdilution wells as an alternative to membrane filter hybridization in which radioisotopes are used to determine genetic relatedness among bacterial strains. Int J Syst Bacteriol 39, 224-229.

Felsenstein, J. (1985). Confidence limits on phylogenies: an approach using the bootstrap. Evolution 39, 783-791.

Fitch, W. M. (1971). Toward defining the course of evolution: minimum change for a specific tree topology. Syst Zool 20, 406-416.

Furlong, M. A., Singleton, D. R., Coleman, D. C. \& Whitman, W. B. (2002). Molecular and culture-based analyses of prokaryotic communities from an agricultural soil and the burrows and casts of the earthworm Lumbricus rubellus. Appl Environ Microbiol 68, 1265-1279.

Hall, T. A. (1999). BioEdit: a user-friendly biological sequence alignment editor and analysis program for Windows 95/98/NT. Nucleic Acids Symp Ser 41, 95-98.

Hiraishi, A., Ueda, Y., Ishihara, J. \& Mori, T. (1996). Comparative lipoquinone analysis of influent sewage and activated sludge by highperformance liquid chromatography and photodiode array detection. $J$ Gen Appl Microbiol 42, 457-469.

Kim, M.-K., Lee, J.-W., Lee, K.-Y. \& Yang, D.-C. (2005). Microbial conversion of major ginsenoside $\mathrm{Rb}_{1}$ to pharmaceutically active minor ginsenoside Rd. J Microbiol 43, 456-462.
Kim, M.-K., Na, J.-R., Lee, T.-H., Im, W.-T., Soung, N.-K. \& Yang, D.-C. (2007). Solirubrobacter soli sp. nov., isolated from soil of a ginseng field. Int J Syst Evol Microbiol 57, 1453-1455.

Kimura, M. (1983). The Neutral Theory of Molecular Evolution. Cambridge: Cambridge University Press.

Kumar, S., Nei, M., Dudley, J. \& Tamura, K. (2008). MEGA: a biologistcentric software for evolutionary analysis of DNA and protein sequences. Brief Bioinform 9, 299-306.

Mesbah, M., Premachandran, U. \& Whitman, W. B. (1989). Precise measurement of the $\mathrm{G}+\mathrm{C}$ content of deoxyribonucleic acid by highperformance liquid chromatography. Int J Syst Bacteriol 39, 159167.

Moore, D. D. \& Dowhan, D. (1995). Preparation and analysis of DNA. In Current Protocols in Molecular Biology, pp. 2-11. Edited by F. W. Ausubel, R. Brent, R. E. Kingston, D. D. Moore, J. G. Seidman, J. A. Smith \& K. Struhl. New York: Wiley.

Saitou, N. \& Nei, M. (1987). The neighbor-joining method: a new method for reconstructing phylogenetic trees. Mol Biol Evol 4, 406425 .

Sasser, M. (1990). Identification of bacteria by gas chromatography of cellular fatty acids, MIDI Technical Note 101. Newark, DE: MIDI Inc.

Singleton, D. R., Furlong, M. A., Peacock, A. D., White, D. C., Coleman, D. C. \& Whitman, W. B. (2003). Solirubrobacter pauli gen. nov., sp. nov., a mesophilic bacterium within the Rubrobacteridae related to common soil clones. Int J Syst Evol Microbiol 53, 485-490.

Ten, L. N., Jung, H.-M., Im, W.-T., Yoo, S.-A. \& Lee, S.-T. (2008). Lysobacter daecheongensis sp. nov., isolated from sediment of stream near the Daechung dam in South Korea. J Microbiol 46, 519-524.

Thompson, J. D., Gibson, T. J., Plewniak, F., Jeanmougin, F. \& Higgins, D. G. (1997). The CLUSTAL_X windows interface: flexible strategies for multiple sequence alignment aided by quality analysis tools. Nucleic Acids Res 25, 4876-4882.

Wayne, L. G., Brenner, D. J., Colwell, R. R., Grimont, P. A. D., Kandler, O., Krichevsky, M. I., Moore, L. H., Moore, W. E. C., Murray, R. G. E. \& other authors (1987). International Committee on Systematic Bacteriology. Report of the ad hoc committee on reconciliation of approaches to bacterial systematics. Int J Syst Bacteriol 37, 463-464. 